\title{
EDITORIAL
}

\section{RIDPHE_R: INTERLOCUÇÕES LATINOAMERICANAS}

\section{Nessa nova edição da RIDPHE_R, Revista Iberoamericana do Patrimônio} Histórico-Educativo, trazemos um número temático organizado pelas pesquisadoras Lucia Martinez Moctezuma, da Universidad Autónoma del Estado de Morelos, México, e Meily Assbú Linhales, da Universidade Federal de Minas Gerais, Brasil, com o tema "Educación Física en Iberoamérica: historia, memoria y patrimonio / Educação Física na Iberoamérica: história, memória e patrimônio. Para além do texto inicial, no qual as organizadoras trazem seus comentários sobre os textos que compõem o temático em questão, há para apreciação e deleite dos leitores mais nove artigos. Nas palavras de Moctezuma e Linhales, na apresentação deste temático, podemos ler que o mesmo "reúne estudos históricos do Brasil, do México, do Uruguai e da Argentina que tematizam prioritariamente as prescrições e práticas para a educação do corpo e para o desenvolvimento da cultura física, em especial na sua configuração como disciplina escolar - a Educação Física”.

Os textos das (os) autoras (es) deste número temático vêm ao encontro das proposições da RIDPHE, Rede Iberoamericana para a Investigação e a Difusão do Patrimônio HistóricoEducativo, no âmbito da qual se criou a RIDPHE_R, ao expressarem a preocupação com a organização de acervos documentais e à formulação de políticas de preservação da memória, em especial, com ações, por vezes, voltadas à organização de acervos institucionais em estado de risco e perda, exigindo urgência na salvaguarda patrimonial, e outros estudos apresentados indiciam o encontro com fontes inéditas e originais às investigações.

Existe um elo muito forte entre vários dos artigos ao incidirem sobre a presença de um modelo de educação corporal norte-americano nos países latino-americanos e também a problemática da formação de professores. Tais artigos deixam transparecer como no final do século XIX, e nas décadas iniciais do século XX, missionários norte-americanos vinculados à Young Men's Christian Association (YMCA) participaram do processo de configuração da Educação Física no Brasil, no Uruguai, na Argentina e no México, com firmes propósitos de participação da formação física, intelectual e moral da juventude. As organizadoras nos esclarecem que essas práticas permitem também visualizar estreita conexão com os preceitos de uma educação moral e evangelizadora.

Essa apropriação de práticas corporais pelos países representados, neste número temático, trazem aspectos de uma circulação cultural empreendida em cada um dos mesmos e 
problematizam diálogos e conexões transnacionais. Nesse sentido, vale comentar o fato de o nome da Associação Cristã supracitada aparecer como YMCA (Young Men' Christian Association), ACJ (Asociación Cristiana de Jóvenes), como era conhecida nos países latinos de língua espanhola e também ACM (Associação Cristã de Moços) como ficou conhecida no Brasil.

Torna-se importante destacar como essa discussão internacional possibilitou, ainda, tal como se percebe nos artigos, a preservação e valorização de fontes importantes a estes estudos, sobretudo, com a organização de Centros de Documentação e similares em vários espaços internacionais. Para além, a organização de exposições, como aquela possibilitada aos pesquisadores da história da educação, história da educação física, formação de professores, dentre outros, abre ainda para a problematização de questão pouco discutida, as exposições como um processo de pesquisa, bem como espaços constituídos de formação de professores. Outrossim, questões de gênero são trazidas à tona, ao se discutir uma outra exposição ocorrida no México quando foram levantadas práticas sobre exercícios corporais femininos na transição do século XIX ao século XX.

A pertinência da discussão e a elucidação de questões exploradas neste dossiê temático em muito enriquecem e enaltecem a qualidade que se tem buscado dar às publicações elaboradas no âmbito da RIDPHE_R, o que em muito se deve aos organizadores dos dossiês e temáticos e aos seus autores. Desta forma, ressaltamos que o agradecimento às organizadoras desse número temático, Professoras Lucia Martinez Moctezuma e Meily Assbú Linhales, é imenso.

As seções que seguem aos artigos, que compõem o temático, trazem, primeiramente, na Seção Resenha, a apresentação e a apreciação de Meily Assbú Linhales do livro da historiadora argentina Lila Caimari "La vida en el archivo: goces, tedios y desvíos en el oficio de la historia", que esclarece, de inicio, tratar-se de obra indicada a todos aqueles que passam boa parte de suas vidas profissionais "nos arquivos e na tessitura da escrita da história".

Na Seção Documento, José Edimar de Souza traz para discussão o documento: Regimento das Escolas Municipais de Novo Hamburgo/RS (1952). Trata-se de documento importante sobre o ensino em município que, atualmente, se destaca como um dos mais importantes economicamente na região do Vale dos Sinos. O autor discute o Regimento das Escolas de Novo Hamburgo no âmbito das reformas educacionais em nível nacional. Trata-se de um documento datilografado, com nove páginas e setenta e um artigos, assinado pelo prefeito municipal e o orientador do ensino municipal do período. O documento vem integralmente transcrito, o que facilita o entendimento da análise com a ilustração da mesma. 
Na seção Notícia iniciamos com a divulgação do próximo dossiê temático da RIDPHE_R, Revista Iberoamericana do Patrimônio Histórico-Educativo, com o título "PATRIMÔNIO-EDUCATIVO E HISTÓRIA ORAL: SUBJETIVIDADES E DIVERSIDADES NA CONTEMPORANEIDADE". Com esta divulgação, conclamamos os interessados à participação com o envio de artigos, resenhas e documentos. Foi disponibilizado o cronograma enviado pelas organizadoras, as Professoras: Maria Lucia Mendes de Carvalho, Andrea Paula dos Santos Oliveira e Suzana Lopes Salgado Ribeiro.

\section{Acessem a Revista em novo endereço:}

https://econtents.bc.unicamp.br/inpec/index.php/ridphe/index

A seção Notícia traz ainda informações sobre importantes eventos que discutirão o Patrimônio Histórico Cultural e Educativo, tais como:

- SEMINÁRIO DO CEMEF/UFMG: DIÁLOGOS TRANSNACIONAIS NA HISTÓRIA DA EDUCAÇÃO FÍSICA;

- V FÓRUM DE MUSEUS UNIVERSITÁRIOS - UFMG / BELO HORIZONTE;

- VIII JORNADAS CIENTÍFICAS DE LA SEPHE / I CONGRESSO NAZIONALE DELLA SIPSE - Palma de Mallorca/España.

Desejamos a todas (os) leitura profícua e instigante!

- Maria Cristina Menezes e Maria de Lourdes Pinheiro 